\title{
Newborn Hearing Screening by Otoacoustic Emissions and Automated Auditory Brainstem Response in Hatay-A prospective study
}

\author{
Emel Demir*, Ali Şafak Dağlı, Ertap Akoğlu, Şemsettin Okuyucu, Tacettin İnandı
}

DOI: $10.17944 / m k u t f d .414152$

Emel Demir: Asst. Prof. Dr., Health School of Mustafa Kemal University, Dept Pediatric Nursing, Hatay, Turkey

Email: emelteksoz@hotmail.com

ORCID iD: https://orcid.org/0000-0002-4884-8989

Ali Șafak Dağlı: Prof. Dr., Medicana International Hospital, Dept of ENT H\&N, Ankara, Turkey

Email: sdagli@medicana.com.tr

ORCID iD: https://orcid.org/ 0000-0002-0199-7223

Ertap Akoğlu: Prof. Dr., Mustafa Kemal University, Tayfur Ata Sökmen Faculty of Medicine, Dept of ENT H\&N, Hatay, Turkey

Email: ertapakoglu@hotmail.com

ORCID iD: https://orcid.org/0000-0001-6908-3607

Semsettin Okuyucu: Prof. Dr., Mustafa Kemal University, Tayfur Ata Sökmen Faculty of Medicine, Dept Of ENT H\&N, Hatay, Turkey

Email: semsettinokuyucu@yahoo.com

ORCID iD: https://orcid.org/0000-0001-8552-2403

Tacettin İnandı: Prof. Dr., Mustafa Kemal University, Tayfur Ata Sökmen Faculty of Medicine, Dept. of Public Health, Hatay, Turkey

Email: inandit@gmail.com

ORCID iD: https://orcid.org/0000-0002-6837-7432

Bildirimler/Acknowledgement

Yazarlar bu makale ile ilgili herhangi bir çıkar catıșması bildirmemișlerdir.

The authors declare that they have no conflict of interests regarding content of this article.

Bu calısma, Türkiye Bilimsel ve Teknik Arastırma

Kurumu (TÜBITAK) tarafından desteklenmiștir.

This study was supported by the Turkish Scientific

and Technical Research Administration (TÜBITAK).

Received: 10.04.2018

Accepted: 28.06.2019

e-ISSN: 2149-3103

Web: http://dergipark.gov.tr/mkutfd
Öz

Otoakustik Emisyon ve Otomatik Beyin Sapı Yanıtları ile Hatay'da Yenidoğan Ișitme Taraması-Prospektif Çalıșma

Amaç: Yenidoğan ișitme taramalarında (UNHS) oto-akustik emisyonlar (OAE) ve otomatik beyin sapı yanıtının (ABR) birlikte kullanımı, ișitme kayıplarının erken tanınmasını sağlamıştır. Bu çalışmanın amacı, otoakustik emisyonlar ve otomatik ișitsel beyin sapı cevabı kullanılarak, Antakya'daki yenidoğan bebeklerde ișitme kaybı sıkığını bulmaktır. Yöntem: Prospektif tasarlanan çalıșma, 18 ay boyunca yenidoğan 7780 bebek ile Antakya'da yapıldı. Bütün yenidoğanlar üç așamalı ișitme tarama protokolü kullanılarak tarandı.

Bulgular: 7780 yenidoğan bebeğin otoakustik emisyon ve bir ABR ile ișitme taraması yapıldı. Üç așamalı yapılan taramadan sonra, 50 yeni doğan bebek ișitme kaybı tanısı aldı. Üçüncü muayene, otomatik beyin sapı yanıt odyometrisinden (aABR) olușuyordu. Bu çalıșma, popülasyonumuzda konjenital ișitme kaybı prevalansının 1000 bebekte 6 olduğunu ortaya koymaktadır.

Sonuç: Bulgularımız genel olarak literatür ile uyumludur. Üç aşamalı protokolün kullanılması TEOAE, DPOAE ve ABR, yenidoğan tarama programlarındaki teșhis edilemeyen ișitme kayıplarında yanlıș pozitif sonuçları önemli ölçüde azaltır. Özellikle ABR, yanlış pozitif sonuçları azaltırken tarama programının verimliliğini arttııır.

Anahtar kelimeler: Yenidoğan ișitme taraması, otoakustik emisyonlar, otomatik beyin sapı yanıtı

\section{Abstract}

Newborn Hearing Screening by Otoacoustic Emissions and Automated Auditory Brainstem Response in Hatay-A prospective study

Aim: The combined use of oto-acoustic emissions (OAES) and auditory brainstem response (ABR) testing in the universal newborn hearing screening (UNHS) has provided to the early detection of this disorder. The aim of this study was to find the rate hearing loss in newborn babies in Antakya by using otoacoustic emissions and automated auditory brainstem response.

Methods: A prospective study was carried out on 7780 newborn who were screened for 18 months in Antakya. All neonates were screened using three step hearing screening protocol.

Results: 7780 newborn babies were examined for hearing screening with otoacustic emissions and a-ABR. Overall, 50 newborn babies resulted with hearing loss after the three steps screening. The third examination consisted of automated brain stem response audiometer (aABR). This study reveals, the prevalence of congenital hearing loss in our population is 6 per 1000 babies.

Conclusion: Our findings are generally in line with previous reports on this matter. Using three step protocol especially a-ABR along with TEOAE and DPOAE at the initial level of testing significantly reduces referral rates in newborn screening programs. Also a-ABR decreases the false positive responses hence increasing the efficiency of screening program.

Keywords: Newborn hearing screening, otoacoustic emissions, auditory brainstem response, newborns

\section{INTRODUCTION}

The incidence of congenital hearing impairment (CHI) is the highest among all the congenital diseases well known worldwide. It ranges from 1-3 hearing impaired children for 1000 births per year (1-4). In Turkey this rate is between 2-6/1000 (5, 6).

Congenital hearing impairment is one of the most common birth defects in neonates (2). The early diagnosis of $\mathrm{CHI}$ is essential in preventing the irreversible consequences in the speech development of the children born with this handicap $(3,7)$. The aim of newborn screening is accurately and rapidly identifing infants with significant hearing loss in least cost-effective method $(2,3,8)$. Two tests have been widely used for infant screening: click or transient evoked autoacoustic emissions (TEOAE) and auditory brainstem response (ABR). Both of these methods show high pass rates in newborn subjects $(2,7,9)$. The report states that in India protocol used in 1 st and 2nd stage of hearing screening are Transient Evoked Otoacoustic Emissions (TEOAE) 
alone and $\mathrm{AABR}$ are used in 3rd stage of hearing screening $(9,10)$.

The aim of this study was to find the rate hearing loss in newborn babies in Antakya by using otoacoustic emissions (transient evoked autoacoustic emission-TEOAE and Distortion Product Otoacoustic Emission-DPOAE) and automated auditory brainstem response (a-ABR).

\section{MATERIALS AND METHODS}

\subsection{Study design}

7780 newborn were screened during November 2006 to July 2008 to estimate the prevalence and compare the referral rates in well born in Antakya Birthgiving Hospital. Following a training period for otoacoustic emissions and $\mathrm{ABR}$, nurses certificated by the ministry of Health were invited for screening the newborn babies. Prior to testing informed consent was obtained from the parents, usually the mother. Also ethical committee approval was obtained from the local ethical committee at Mustafa Kemal University. In this study was applied a three-step screening protocol using TEOAE, DPOAE and A-ABR. All babies born in the hospital were screened for hearing loss by TEOAE within 24 hours after birth or before their discharge within 3 days after delivery. The babies failed from the TEOAE were called for retesting 15 days after the initial examination for TEOAE and DPOAE. Babies failed from the finally test were called 1 month later for a-ABR.

Before measurements a questionnaire was filled about the gestational age, congenital anomalies, consanguineous marriages, birth weight, hearing loss in the family, maternal disease, ototoxic drug etc. Babies followed in the Intensive care unit were not included only the babies with neonatal jaundice were examined.

Babies with positive test (no traceable transient evoked otoacoustic emissions) who did not attend to second test were excluded from the study.

All measurements were made in a sound proof cabin $(1.5 \times 2.5 \mathrm{~m})$ with an 7 to $20 \mathrm{~dB}$ (average $13 \mathrm{~dB}$ ) background noise. Testing time for otoacoustic emissions an lasted between 0.5 to 2 minutes but 3 to 5 minutes was given for each otoacoustic measurement whereas 5 to 12 minutes was given for each a-ABR test.

\subsection{TEOAE- Transient evoked otoacustic}

\section{emission}

TEOAE screening was performed using the Otodynam- ic Analyzer ILO 88 (Otodynamics UK). Following otoscopic examination babies with debris in their external ear were aspirated or cleaned by cotton. Then with a rubber tipped probe suitable for their external ears were examined by sending clicks a rate of 50 per sec. At 80 microseconds duration and $80 \mathrm{~dB}$ peak SPL for the first three clicks of four stimulus sets, with a fourth nonlinear balancing click of opposite polarity that is three times the amplitude of the first three. Alternate responses are averaged and stored in two separate waveforms that are then analyzed and cross-compared, resulting in a percent number called "reproducibility". The frequency bands used were 1, 1.5, 2, 3 and $4 \mathrm{kHz}$.

\subsection{DPOAE-Distortion product otoacoustic}

\section{emission}

For the distortion product otoacoustic emissions ILO 292 Otodynamic analyzer was used in F1: 65 dB, F2: $55 \mathrm{~dB}$ with an F1/F2 ratio: 1.22. The frequencies measured were at 1001, 1501, 2002, 3003, 4004, 6006 and $7996 \mathrm{~Hz}$. Ears with emissions in at least three frequencies were in pass criteria. Emissions in less than 3 frequencies were taken into "refer" group.

\section{4. a-ABR- automated auditory brainstem}

\section{response}

IaBaseII Interacoustics automated brainstem evoked response audiometer was used. Sleeping or silent babies were analyzed by using five disposable electrodes attached to the back or right and left ears, forehead, hair line and maxilla. $100 \mu$ s clicks at $40 \mathrm{ohms}$ were presented. BERA Test lasted between 20-120 seconds but cleansing of the field and placement of the disposable electrodes took 5 to 10 minutes.

If one or both ears passed from the otoacoustic emission test the new born was considered negative and further testing was not required. When both ears failed to pass TEOAE the new born was considered positive and scheduled for the next examination 15 days later. The second testing consisted of TEOAE and DPOAE measurement. The third measurement for positive cases included automated a-ABR.

\subsection{Statistical analyses}

The quantitative data were entered, cleaned and analysed in SPSS 13 windows packet program. Statistical analysis were performed using $\mathrm{x} 2$ and $\mathrm{T}$ test, further analysis were performed by using logistic regression analysis. For 
all of the statistical analyses, a probability value of $\mathrm{p}<0.05$ was considered statistically significant.

\section{RESULTS}

7780 newborn babies were examined for hearing screening with TEOAE, DPOAE and a-ABR. Babies were examined within 3 days after delivery by using transient evoked otoacoustic emissions for 18 months. The positive results (with no traceable otoacustic emissions in both ears) were higher on the first day of examination as expected $(17.2 \%)(\mathrm{p}<0.05)$ (Table 1$)$. The rate of negativity increased by the second and third day measurements $(8.1 \%$ and $8.7 \%) .1224$ (15.7\%) babies were called for retesting 15 days after the first examination. 420 (34.3\%) babies were lost for follow up. 804 babies were examined using both TEOAE and DPOAE. These tests revealed 66 positive results (with no traceable emissions). 50 babies were diagnosed using a-ABR as hearing loss $(0.6 \%)$.

Table 1. The relationship between follow-up is called up with days of the test is applied

\begin{tabular}{llclclll} 
& \multicolumn{2}{c}{ Pass } & \multicolumn{2}{c}{ Refer } & \multicolumn{2}{c}{ Total } & p-value \\
Days & $\mathbf{n}$ & $\mathbf{\%}$ & $\mathbf{n}$ & $\mathbf{\%}$ & $\mathbf{n}$ & $\%$ & \\
First & 5235 & 82.7 & 1092 & 17.2 & 6327 & 100 & $>0.001$ \\
Second & 907 & 91.7 & 82 & 8.2 & 989 & 100 & x $2=61.629 \mathrm{a}$ \\
Third & 125 & 91.2 & 12 & 8.7 & 137 & 100 & \\
Fourth & 289 & 88.3 & 38 & 11.6 & 327 & 100 &
\end{tabular}

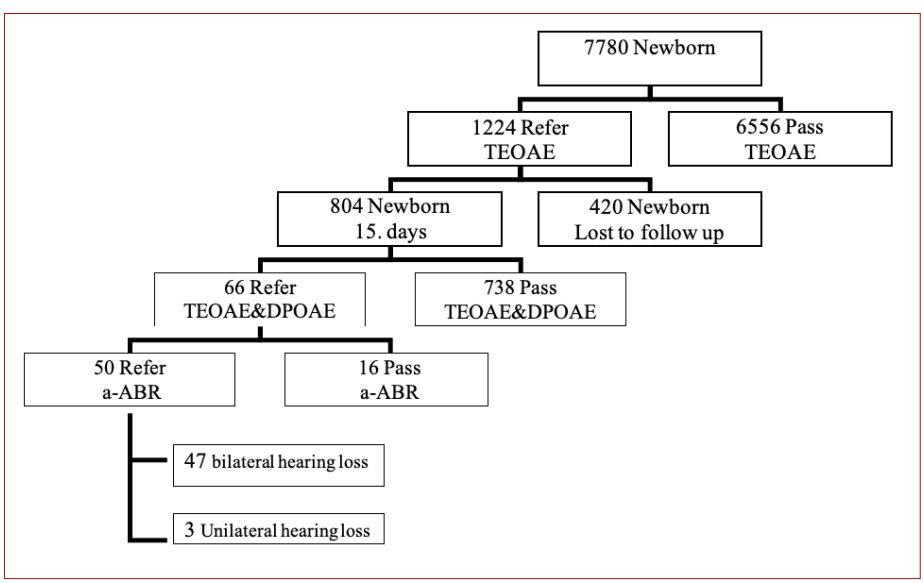

Figure 1. Results of newborn hearing screening

Table 2 shows the effect of maternal and fetal factors on hearing loss. Babies from consanguineous marriage revealed significantly higher rate of hearing loss (1.5\%) $(\mathrm{p}<0.05)$. In our study families with congenital hearing loss subjects revealed a higher rate of birth with hearing impaired babies $(4.5 \%)(\mathrm{p}<0.05)$. The rate of hearing loss was also higher in newborn babies with neonatal jaundice ( 1 in 6 babies with neonatal jaundice). In our group only one among 6 babies treated with phototherapy revealed bilateral hearing loss, statistical analysis revealed a positive correlation $(\mathrm{p}<0.05) .24$ babies were born with congenital anomalies and 5 of them revealed bilateral hearing loss $(20.8 \%)(\mathrm{p}<0.05)$.

\section{Table 2. Effect of maternal and fatal factors on hearing loss}

$\begin{array}{ccccc}\text { Profile } & \text { Normal } & \begin{array}{c}\text { Hearing } \\ \text { loss }\end{array} & \text { Total } & \text { Statistical } \\ & \mathbf{n}(\%) & \mathbf{n}(\%) & \mathbf{n}(\%) & \text {-value }\end{array}$

Maternal Factors

Consanguineous marriage

$\begin{array}{lllll}\text { Yes } & 1775(98.4) & 28(1.5) & 1803(100) & \mathrm{p}=0.000 \\ \text { No } & 5955(99.6) & 22(0.0) & 5977(100) & \mathrm{x} 2=30.455 \mathrm{~b}\end{array}$

Consanguineous marriage

degree

$\begin{array}{rllll}\text { First degree } & 1358(98.1) & 25(1.8) & 1383(100) & \mathrm{p}=0.000 \\ \text { Second degree } & 301(99.0) & 3(0.9) & 304(100) & \mathrm{x} 2=37.767 \mathrm{a} \\ \text { Third degree } & 116(100) & 0(0.0) & 116(100) & \\ \text { None } & 5955(99.6) & 22(0.3) & 5977(100) & \\ \text { in the family } & & & & \\ \text { Yes } & 188(95.4) & 9(4.5) & 197(100) & \mathrm{p}=0.000 \\ \text { No } & 7542(99.4) & 41(0.5) & 7583(100) & \mathrm{x} 2=48.785 \mathrm{~b}\end{array}$

Hearing loss in the family

degree

$\begin{array}{rllll}\text { First degree } & 58(92.0) & 5(7.9) & 63(0.8) & \mathrm{p}=0.000 \\ \text { Second degree } & 98(97.0) & 3(2.9) & 101(1.3) & \mathrm{x} 2=65.239 \mathrm{a} \\ \text { Third degree } & 32(96.9) & 1(1.0) & 33(0.4) & \\ \text { None } & 7542(99.4) & 41(0.5) & 7583(100) & \end{array}$

Fatal Factors

Neonatal jaundice

$\begin{array}{llllll} & \text { Yes } & 6(0.1) & 1(2.7) & 7(0.2) & \mathrm{p}=0.000 \\ \text { Congenital Anomaly } & \text { No } & 7737(99.5) & 36(0.4) & 7773(99.8) & \mathrm{x} 2=15.831 \mathrm{~b} \\ & & & & & \\ & \text { Yes } & 19(79.1) & 5(20.8) & 24(100) & \mathrm{p}=0.000 \\ & \text { No } & 7711(99.4) & 45(0.5) & 7756(100) & \mathrm{x} 2=153.696 \mathrm{~b}\end{array}$

As seen in Table 3, statistically significant differences were found in logistic regression analysis, such as; "Congenital Anomaly" ( $p=0.000)$, "Consanguineous marriage" $(p=0.000)$, "Hearing loss in the family" $(p=0.000)$. Risk of hearing loss is increased congenital anomaly by 43.0 times, while it is increased consanguineous marriage by 3.6 times and is increased hearing loss in the family by 8.2 times. 


\begin{tabular}{|c|c|c|c|c|c|}
\hline & & \multirow{2}{*}{ p-value } & \multirow{2}{*}{ O.R } & \multicolumn{2}{|c|}{$\% 95.0$} \\
\hline & & & & Min & $\operatorname{Max}$ \\
\hline \multirow[t]{2}{*}{ Congenital Anomaly } & No & 0.000 & 1 (Ref) & 14.7 & 125.8 \\
\hline & Yes & & 43.0 & & \\
\hline \multirow[t]{2}{*}{ Consanguineous marriage } & No & 0.000 & 1 (Ref) & 2.0 & 6.4 \\
\hline & Yes & & 3.6 & & \\
\hline \multirow[t]{2}{*}{ Hearing loss in the family } & No & 0.000 & 1 (Ref) & 3.9 & 17.6 \\
\hline & Yes & & 8.2 & & \\
\hline
\end{tabular}

\section{DISCUSSION}

With the implementation of UNHS program in 2005 in Turkey, the detection of newborns with hearing loss (5). UNHS has been carried out by a three-step protocol using TEOAE, DPOAE and AABR in Antakya for almost 18 months. Hacettepe University and Marmara Universities audiology departments for the first time in our country starting in neonatal hearing screening (6), Turkey Scientific and Technical Research Institute with support of our country with a population of 1.5 million 9 The largest province, the annual number of live births, 24000, general fertility rate of $0.68 \%$ in the province of Hatay in 7780 newborn babies were applied without regard to whether there is a risk factor. The results of screening newborns in Turkey and the world emission rates were similar for the province of Hatay.

According to the Health Care Guidelines for Children of the Municipality, UNHS, maternal complications can cause maternal and fatal complications, with such risks potentially leading to the need for ICU treatment and being associated with the risk of hearing impairment $(1,11)$. Referral rates in high risk babies were more than well born babies in both DPOAE and AABR testing as observed in other studies. Estimated prevalence of congenital hearing loss in this current population is 1.42 per 1000 babies (9). Approximately 55\% of neonates in the o the neonatal intensive care unit had risk factors related to permanent hearing loss (2). Population of newborns of low and high risk for hearing impairment, the following were encountered: family history of hearing deficiency, congenital anomalies, ototoxicity, ventilation for more than 24 hours, prematurity and low weight $(1,8)$. In our study, risk of hearing loss maternal and fatal is increased congenital anomaly, neonatal jaundice, consanguineous marriage and hearing loss in the family. Gisele M. L. Lima (12) supports the findings of this research study, the effect of having hearing loss in the family is the same. The study has established that the incidence of sensorineural hearing loss among infants with neonatal jaundice is significantly higher than in those without neonatal jaundice, which might reflect that efforts to prevent and/or timely treat severe neonatal jaundice are current- ly limited (13). Gisele M. L. Lima (12) by Berg, Spitzer (14) neonatal jaundice his studies, the data support the association with hearing loss.

\section{CONCLUSION}

Early identification of hearing loss and early intervention significantly improves speech and language development. Three step hearing screening programs are rarely being carried out in Turkey. The present study was carried out to analyze the prevalence and referral rates using three step hearing screening protocol. From the current study of neonatal hearing screening, we conclude that the prevalence of congenital hearing loss is $0.6 \%$. Since identified babies were from high risk group we strongly recommend hearing screening of high risk neonates in developing countries.

\section{REFERENCES}

1. Van Noort-van der Spek IL, Goedegebure A, Hartwig NG, Kornelisse RF, Franken MJP, Weisglas-Kuperus N. Normal neonatal hearing screening did not preclude sensorineural hearing loss in two-yearold very preterm infants. Acta paediatrica. 2017;106(10):1569-75.

2. Wenjin W, Xiangrong T, Yun L, Jingrong L, Jianyong C, Xueling W, et al. Neonatal hearing screening in remote areas of China: a comparison between rural and urban populations. The Journal of international medical research. 2017:300060517706643.

3. Beqiri E, Nika D. Universal neonatal hearing screening in Albania, 2009-2012. Materia socio-medica. 2015;27(1):13-4

4. Hardelin JP, Denoyelle F, Levilliers J, Simmler MC, Petit C. [Hereditary deafness: molecular genetics]. Medecine sciences : M/S. 2004;20(3):311-6.

5. Kirkim G, Serbetcioglu B, Erdag TK, Ceryan K. The frequency of auditory neuropathy detected by universal newborn hearing screening program. International journal of pediatric otorhinolaryngology. 2008;72(10):1461-9.

6. G. Aydan Genç FB, Maviş E. Kayıkçı, Didem Türkyılmaz, Zerrin Fırat, Öznur Duran, Özlem Ulusoy, Erol Belgin, Bilgehan Budak, Gülsevin Tekinalp, Murat Yurdakök, Pule Yiğit, Ayşe Korkmaz. Hacettepe University Newborn Hearing Screening Results (In Turkish). journal children health and disaese 2005;48(2):119-24.

7. Levit Y, Himmelfarb M, Dollberg S. Sensitivity of the Automated Auditory Brainstem Response in Neonatal Hearing Screening. Pediatrics. 2015;136(3):e641-7.

8. Sabbag JC, Lacerda ABM. Neonatal Hearing Screening in primary health care and family health care. CoDAS. 2017;29(4):e20160102.

9. Vignesh SS, Jaya V, Sasireka BI, Sarathy K, Vanthana M. Prevalence and referral rates in neonatal hearing screening program using two step hearing screening protocol in Chennai - A prospective study. International journal of pediatric otorhinolaryngology. 2015;79(10):1745-7. 
10. Bonfils P, UzielA, PujolR. Screening for auditory dysfunction in infants by evoked oto-acoustic emissions. Archives of otolaryngology--head \& neck surgery. 1988;114(8):887-90.

11. Adelola OA, Papanikolaou V, Gormley P, Lang J, Keogh IJ. Newborn hearing screening: a regional example for national care. Irish medical journal. 2010;103(5):146-9.

12. Gisele M. L. Lima STMM, Maria Francisca C. Santos. Hearing Screening in a neonatal intensive care unit. J Pediatrics (Rio J).
2006;82(2):110-4.

13. Olusanya BO, Somefun AO. Sensorineural hearing loss in infants with neonatal jaundice in Lagos: a community-based study. Annals of tropical paediatrics. 2009;29(2):119-28.

14. Berg AL, Spitzer JB, Towers HM, Bartosiewicz C, Diamond BE. Newborn hearing screening in the NICU: profile of failed auditory brainstem response/passed otoacoustic emission. Pediatrics. 2005;116(4):933-8. 